\title{
Analysis the Influences of Food Prices (Volatile Food) in South Sulawesi 2011-2017
}

\author{
Anas Iswanto Anwar ${ }^{1}$, Sri Undai Nurbayani ${ }^{2}$ and Putri Rezky Indria ${ }^{3}$ \\ ${ }^{1}$ Hasanuddin University, Indonesia, e-mail: aianwar@,fe.unhas.ac.id \\ ${ }^{2}$ Hasanuddin University, Indonesia, e-mail: sri.undai@gmail.com \\ ${ }^{3}$ Hasanuddin University, Indonesia, e-mail: putrirezkyindria@gmail.com
}

\begin{abstract}
The aim of this study is to analyze the effect of the amount of money in circulation, import, and the number of populations on volatile foods in South Sulawesi. This research uses secondary data which is time series as much as 78 periods from January 2011 until June 2017 sourced from BI (Indonesian Bank) and BPS (Central Institution of Statistic) analyzed by ARCH-GARCH (Auto Regressive Conditional Heteroscedasticity-Generalized Auto Regressive Conditional Heteroscedasticity) using program Eviews 8. The result of this research shows that Volatile Foods variable identified Heteroscedasticity, because it does not fluctuate throughout of the year. The result of GARCH shows that the amount of money in circulation has positive and significant effect, the import has positive and significant effect, and the number of populations has negative and significant effects on the Volatile foods in South Sulawesi.
\end{abstract}

Keywords: Volatile foods, the amount of money in circulation, Import, Number of populations

\section{Introduction}

Volatility is a complex issue that affects various fields including food security, financial markets, and trade flows (Miguez and Michelena, 2011). Volatility almost occurs in all countries, especially developing and poor countries, so this issue becomes an international issue. In the international sphere, price volatility, especially for the food sector, is one of the problems.

Volatility is basically a natural phenomenon. Indonesia as a developing country is vulnerable to food price volatility. This is because some staple food needs are still imported, so that if world food prices are not stable it will affect domestic price conditions, as expressed by (Bourdon, 2011) that unstable food prices are a risk for developing countries. If food prices increase, inflation will rise and economic growth will decline which will affect the household conditions of the community, especially the poor. However, the main key in controlling inflation is the ability to mitigate fluctuations in the price of food commodities (Prastowo et al., 2008).

Food price fluctuations are important because they can have a negative impact on people's purchasing power. Increasing the price of a commodity causes real income to fall, so that buyers reduce purchases (Sugiarto et al. 2007). The decreasing purchasing power of these people prevents people from accessing food needs. If this happens, people's welfare will decrease. Fluctuations in food prices also have a negative effect on the poor population, because higher food prices cause serious poverty basket inflation which increases the percentage of the poor. Failed harvests combined with a slow reaction from the Government to replace local food products with imports are the cause of inflationary pressures.

High and low inflation rates are not what is desired by the monetary authority because if high inflation will take the level of the welfare of the people of South Sulawesi Province, while low inflation will cause the wheels of the economy to turn low. Whereas, money supply is increasing, and people's purchasing power is increasing. Demand for goods is increasing and will reduce supply so that interforeign transactions (imports) occur which will have an impact on inflation.

The controlled price of food commodities will be one of the supporting factors of success in controlling the rate of inflation (Prastowo et al., 2008). Controlling the inflation rate is a consideration that high and unstable inflation can have an impact on the economy of the community. High inflation will cause people's real income to decline, resulting in a decrease in people's purchasing power. 
Furthermore, unstable inflation will create uncertainty for economic actors in decision making (Riyadh et al., 2009).

Volatility comes from the basic word volatile (volatile). This term refers to conditions that have an unstable connotation, tend to vary and are difficult to estimate. Volatility can be illustrated by the tendency of a data to fluctuate rapidly over time. Often found there is a grouping of volatility (volatility clustering) in the data, namely the volatility of large values over a certain period of time and small value for another time period or in other words, a number of errors that are relatively similar in some time.

Experts distinguish inflation from food and non-food inflation (Walsh, 2011). Food inflation according to Walsh can be great if food price shocks are more volatile than non-food price shocks, especially when there is a food crisis. Food inflation as a whole tends to be higher and more stable than non-food inflation especially in developing and poor countries.

Volatile foods are inflation such as harvest, natural disturbances, or factors in the development of domestic food commodity prices as well as developments in international food commodity prices. Food is everything that comes from biological sources of agricultural products, plantations, forestry, fisheries, livestock, water, and water, both processed and not processed which are intended as food or drinks for human consumption, including food additives, food raw materials, and other materials used in the process of preparing, processing and or making food or beverages. Mangilep (2015) points out that food security is an important aspect in South Sulawesi Indonesia.

Theory of the Relationship between the Number of Circulating Money and Volatile Foods (Inflation). Quantitative theory according to Irving Fisher sees the function of money as a means of exchange. According to him, if there is a transaction between the seller and the buyer then there is an exchange between money and goods / services, so the value of money will be equal to the value of the goods / services. In every transaction there are always buyers and sellers. The amount of money paid by the buyer must be the same as the money received by the seller.

Quantity theory does not only state that the money supply is a factor causing changes in price levels. The quantity theory of money is also related to the theory of (1) the proportionality of the amount of money with the price level, (2) the monetary transmission mechanism, (3) the neutrality of money, and (4) the monetary theory of price levels. One of the figures of this monetarist is Milton Friedman economist who won the Nobel prize in economics in 1976. This figure made a very famous statement, namely that inflation is always and everywhere a monetary phenomenon.

Theory of Relationship between Imports and Volatile Foods (Inflation). According to this structural theory there are 2 structural problems in developing economies that can cause inflation. First, export revenues are not elastic, namely the slower growth in export value compared to the growth of other sectors. This is due to worsening terms of trade and production of export goods that are less responsive to price increases. The slowdown in export growth will hamper the ability to import goods needed. Often developing countries carry out import substitution policies even at high costs and result in high prices of goods that cause inflation.

Comparative Theory of Advantage David Ricardo first introduced the concept of comparative advantage in the early 19th century with the law of comparative advantage which states that every country has a comparative advantage in something and benefits by trading it in exchange for other goods (Lindert and Kindleberger, 1995).

Heckscher-Ohlin later developed Ricardo's theory of comparative advantage by stating that countries export goods that use an abundant factor of intensive production and import goods that use intensively rare factors of production. The costs for production factors are explained by the Opportunity Cost Theory, that the cost of a commodity is the number of second commodities that must be sacrificed in order to obtain sufficient factors of production or sources of production to produce an additional unit of the first commodity.

Relationship Theory Between Population (Population) and Volatile Foods (Inflation). Aggregate demand (AD) is the relationship between the aggregate price level and the amount of output 
requested. In other words, the aggregate demand curve states the amount of goods and services people want to buy at each price level. In aggregate demand there is a quantity equation that is the money supply multiplied by the velocity of money equal to the price level multiplied by the amount of output. If the velocity of money is constant, then this equation states that the amount of money in circulation determines the nominal value of output, which in turn is a product of the price level and the amount of output.

Quantity equation can be rewritten in the form of supply and demand for real money balance M/P equals demand $(\mathrm{M} / \mathrm{P}) \mathrm{d}$ and that demand is proportional to output. The velocity of money is the other side of the money demand parameter. The assumption of a constant velocity of money is equal to the assumption that the demand for real money balance for each unit of output is constant.

The aggregate demand curve (AD) shows the relationship between the level of price and the amount of goods and services requested. The curve is described for the value of a certain amount of money in circulation. Downward aggregate demand curve, the higher the price level, the lower the real M/P balance level, and therefore the lower the number of goods and services requested.

Malthus proposed that long-term inflation is the result of an increasing population. He suggested that the human population could potentially grow exponentially. The main problem with this, according to Malthus, is that increasing supply of commodities used for our basic needs tends to grow only in arithmetic. This mismatch creates competition for resources, which causes price increases, especially at a time of rapid population increase.

\section{Research Methodology}

The data used is secondary data with monthly Time Series periods January 2011 - June 2017. The data used are volatile foods data (inflation classification), the money supply, food imports, and the population derived from the Statistics Agency website, Bank Indonesia and various sites related to research. In addition, the author also conducted literature studies by reading journals, books, internet articles, and various other literature.

The model used in this study is the ARCH-GARCH (Autoregressive Conditional HeteroscedasticityGeneralized Autoregressive Conditional Heteroscedasticity) model using the program Eviews 8, the reason why this method is used is that the purpose of this model is to calculate the amount of volatility of food prices. The price of food ingredients is considered to have experienced a sharp increase and decline, so that it is necessary to calculate the value of volatility. Volatility occurs because the residual variance is not constant so that homoskedasticity cannot be fulfilled, while the method in tune with ARCH-GARCH is the VAR (Vector Autoregression) and ECM (Error Correction Mechanism) methods but cannot be used in this study due to the weakness of the method. is this VAR method can only see a lot of variables, more suitable for simultaneous data and not to see volatility (Gujarati, 2004), whereas in this study the price of food ingredients is very volatile, and for the ECM method can only explain short-term short information from the data (Vamvoukas, 1998). The equation in the ARCH model is as follows: (Nachrowi, 2006)

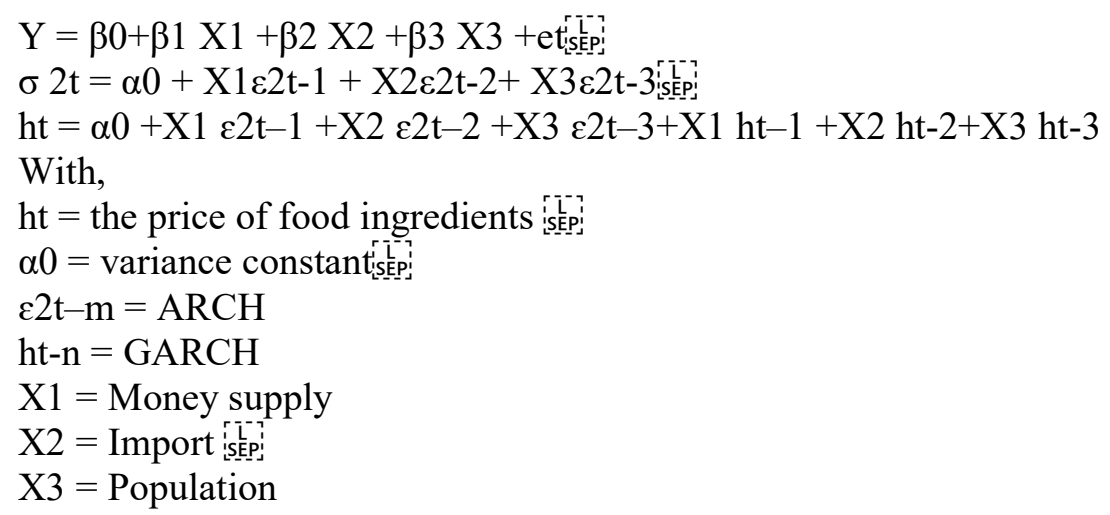




\section{Result and Discussion}

The analysis will be carried out on the effect of the money supply, imports, and the population on volatile foods in South Sulawesi Province using the ARCH-GARCH method. Before testing the ARCH-GARCH, it will take several steps. First is to test stationarity for the data to be analyzed. The second is identification of the Box-Jenkins model by observing the results of the stationary test. The third is to test the effect of ARCH. The ARCH effect test will determine whether the selected model can be further analyzed using the ARCH-GARCH model. The fourth is the estimation of the ARCHGARCH model by choosing the best model. Fifth is the evaluation of the model using the normality test and ARCH-LM test to determine the selected ARCH-GARCH model is free from the ARCH effect. Sixth, Testing of GARCH, and knowing the direct effect of independent variables on the dependent variable.

In table 1 . it can be seen that stationary volatile foods variable at level with probability is 0.0000 which shows significant Volatile foods, the money supply is stationary on the second difference with a probability of 0.0000 which shows significant money supply, stationary food imports on the second difference with probability amounting to 0.0001 which shows significant food import, and stationary population at first difference with a probability of 0.0000 which indicates a significant population. In full can be seen in the table as follows:

Table 1. Uji Stationer Data (Augmented Dickey-Fuller)

\begin{tabular}{|l|l|l|l|}
\hline \multicolumn{1}{|c|}{ Variable } & \multicolumn{1}{|c|}{ Stationer } & T-Statistic & Probabilities \\
\hline Volatile Foods & Level INF has a unit root & -7.150849 & 0.0000 \\
\hline money supply & Second difference D(JUB,2) & -7.794781 & 0.0000 \\
\hline Import & Second Difference: D(IMPOR,2) & -17.66095 & 0.0001 \\
\hline Population & First Difference : D(JP) & -9.300386 & 0.0000 \\
\hline
\end{tabular}

Source: data Eviews 8.0.

Test the Box-Jenkins AR-MA model (Autoregressive - Moving Average). The Box-Jenkins model was determined after stationary testing. Some Box-Jenkins models are Auto Regressive (AR), Moving Average (MA). Estimation of the ARMA parameters in the volatile food's variable, the money supply, imports, and the population can be seen in Table 2. The best model was chosen after doing several ARMA model simulations. The selection criteria for the ARMA model are based on a significant estimation coefficient, having the largest R-Squared and adjusted R-Squared, the smallest AIC and SIC values, and relatively small Standard Error of Regression and Sum Square Residual values.

Table 2. Model Box Jenkins (AR-MA)

\begin{tabular}{|l|l|}
\hline \multicolumn{1}{|c|}{ Variable } & \multicolumn{1}{c|}{ The Best Model } \\
\hline Volatile foods & $\mathrm{AR}(1)-\mathrm{AR}(2)-\mathrm{MA}(1)+\mathrm{MA}(2)+\mathrm{MA}(3)$ \\
\hline Money supply & $\mathrm{AR}(1)-\mathrm{MA}(1)-\mathrm{MA}(2)$ \\
\hline Import & $\mathrm{AR}(1)+\mathrm{AR}(2)-\mathrm{MA}(1)+\mathrm{MA}(2)-\mathrm{MA}(3)$ \\
\hline Population & $\mathrm{AR}(1)+\mathrm{AR}(2)-\mathrm{MA}(1)$ \\
\hline
\end{tabular}

Source: data Eviews 8.0.

The ARCH-GARCH model can be used to calculate volatility if there is an ARCH effect on the selected AR-MA model. The ARCH effect test is intended to find out whether there is a heteroscedasticity problem in the four variables analyzed. The results of testing the effect of ARCH in Table 3 show that only the variable volatile foods have heteroscedasticity problems because the $\mathrm{ARCH}$ effect is found in each model. The ARCH effect found in each of the best models indicates 
that the calculated volatility varies between times. The presence or absence of the ARCH effect is indicated by the probability value in the volatile food's variable. The probability of volatile foods is less than the real level of 5 percent, so it can be concluded that there is a problem of heteroscedasticity of volatile foods variables. Heteroscedasticity problems can be solved using the ARCH-GARCH model.

Table 3. Identification effect ARCH on variable dependent and independent

\begin{tabular}{|l|l|l|l|}
\hline \multicolumn{1}{|c|}{ Variabel } & \multicolumn{1}{|c|}{ Model AR-MA } & F-Statistic & \multicolumn{1}{c|}{ Sig } \\
\hline Volatile foods & $\mathrm{AR}(1)-\mathrm{AR}(2)-\mathrm{MA}(1)+\mathrm{MA}(2)+\mathrm{MA}(3)$ & 9,876617 & 0,002 \\
\hline Money supply & $\mathrm{AR}(1)-\mathrm{MA}(1)-\mathrm{MA}(2)$ & 0,015608 & 0,900 \\
\hline Import & $\mathrm{AR}(1)+\mathrm{AR}(2)-\mathrm{MA}(1)+\mathrm{MA}(2)-\mathrm{MA}(3)$ & 0,000176 & 0,9895 \\
\hline Population & $\mathrm{AR}(1)+\mathrm{AR}(2)-\mathrm{MA}(1)$ & 3,708479 & 0,0580 \\
\hline
\end{tabular}

Source: data Eviews 8.0.

Whether or not the ARCH effect in the ARMA model will determine the model for subsequent analysis using the ARCH-GARCH. Based on Table 3, only volatile foods have an ARCH effect, so that volatility analysis can be done using the ARCH-GARCH. The best ARCH-GARCH model is chosen based on the criteria, namely, all significant coefficients in the variance equation, have the smallest value, AIC value and SIC, and have a positive value for all coefficients in the variance equation. Based on the existing criteria, the ARCH-GARCH model selected for each volatile food's variable shown in Table 4 is as follows:

Table 4. Model ARCH-GARCH of volatile foods

\begin{tabular}{|c|c|c|}
\hline Model & \multicolumn{1}{|c|}{ Coefficient } & probabilities \\
\hline ARCH (5) & $-0,106806$ & 0,0386 \\
\hline
\end{tabular}

Source: data Eviews 8.0.

Based on Table 4, the ARCH model is the best model for volatile foods. After choosing the best ARCH-GARCH model, the next thing to do is to evaluate the model. Model evaluation can be done through normality test by observing the Jarque-Bera statistical value. Jarque-Bera statistical test results can be seen in Table 5. The results of the normality test show that the Jarque-Bera value is not statistically significant which means that the error of the model is normally distributed, so the ARCHGARCH model shown in Table 3 is still the best model. Therefore the ARCH-GARCH test is free from the ARCH effect.

In table 1, variable money supply (X1) shows a positive and significant relationship to volatile foods in the province of South Sulawesi in the period 2011-2017. This is indicated by the coefficient value of 13.994 and the probability value below that of the 0.05 level of 0.000 . That is, if the money supply increases by Rp. 13,994 thousand will result in an increase in the value of volatile foods in South Sulawesi Province in 2011-2017.

The results of calculations for the money supply, foodstuff imports and the population of volatile foods shown in Table 5 are as follows: 
Table 5. Regression results influence the money supply, imported food materials, population to volatile foods

\begin{tabular}{|l|c|c|}
\hline \multicolumn{1}{|c|}{ Variable } & Coefficient & Sig \\
\hline Constant & 1620.803 & 0,0000 \\
\hline Money supply & 13,99498 & 0,0000 \\
\hline Imported food material & 1,290452 & 0,0029 \\
\hline Population & $-137,0858$ & 0,0000 \\
\hline R Square & 0,073402 & \\
\hline Adjusted r-square & 0,035838 & \\
\hline
\end{tabular}

Source: data Eviews 8.0.

Based on the regression results above can be written in the form of the following equation: $\mathrm{Y}=1620,803+13,99498 \mathrm{X} 1+1,290452 \mathrm{X} 2-137,0858 \mathrm{X} 3$

In table 1. Food import variables (X2) show a positive and significant relationship to volatile foods in the province of South Sulawesi in the period 2011-2017. This is indicated by the coefficient value of 1.290452 and the probability value below that of the 0.05 level of 0.000 . That is, if the import of foodstuffs increases by Rp. 1,290,452 million, it will cause an increase in the value of volatile foods in South Sulawesi Province in 2011-2017.

In table 5, variable population (X3) shows a negative and significant relationship to volatile foods in South Sulawesi Province for the period 2011-2017. This is indicated by the coefficient value of 137.0858 and the probability value below that of the 0.05 level of 0.000 . That is, if the population increases by $\mathrm{Rp} 137$ thousand it will result in a decrease in the value of volatile foods in South Sulawesi Province in 2011-2017.

Based on the estimation results in table 3. variable money supply has a positive effect on volatile foods with a regression coefficient of 13.994. And through a significance level greater than the probability value of $0.05>0,000$, the money supply has a significant positive effect on volatile foods in the province of South Sulawesi.

According to Milton Friedman, the theory of money demand basically states that the demand for public money is determined by a number of economic variables, including economic growth, interest rates, and price levels. In line with the theory of money demand, the price level or inflation rate will only change if the money supply does not match the amount requested or required by an economy.

Thus the hypothesis which states that money supply has a positive influence on the value of volatile foods significantly in South Sulawesi Province in the period 2011-2017 is proven in accordance with the results of the study of the regression results (table 5).

Based on the estimation results in table 5. Food import variables (X2) show a positive and significant relationship to volatile foods in the province of South Sulawesi in the period 2011-2017. This is indicated by the coefficient value of 1.290452 and the probability value is smaller than the confidence level of $0.000<0.05$.

Import is an activity to enter goods into a part area. Import transactions are trades by entering goods from abroad into Indonesian customs areas by complying with the provisions of applicable statutory regulations (Tandjung, 2011). In this study, the import used was the import of food ingredients in South Sulawesi Province.

Based on the above phenomena both in terms of structural theory and data development stated that if the import of foodstuffs in the community decreases or increases, the price level will increase, causing inflation to increase or decrease. This is in line with the results of research conducted in Table 5, that if the increase or decrease in food imports will result in an increase/decrease in the value of volatile foods. 
Thus the hypothesis which states that the import of food ingredients has a positive influence on the value of volatile foods significantly in South Sulawesi Province in the period 2011-2017 is proven in accordance with the results of the study of the regression results (table 5).

Residents are all people who live in a certain area at a certain time. The population is the amount that occupies an area at a certain time. To find out the population of a region or country can be done in three ways, namely population census, population survey and population registration. In the study population used is the number of joint populations between women and men who settled in all regions in South Sulawesi Province.

Aggregate demand theory suggests that if the demand for a society increases it will cause money supply to increase so that the price of an item increases and causes an increase in inflation. This means that in the aggregate demand theory, increasing population growth also causes an increase in the price level.

This is not in line with the estimation results, namely the population has a negative effect on the value of volatile foods. But the fact has been found that every year from 2011-2017 shows a significant increase and the volatile foods value does not show an increase that occurs every year. In 2012 the volatile foods value showed a decreasing trend, while the number of residents still shows an increasing trend. Based on the facts above shows that if the population increases, it will cause a decrease in volatile foods. The price of rice in South Sulawesi is lower than the national rice price. This is because rice production in South Sulawesi is greater than the needs of its population, so the availability of rice has a surplus.

Thus the hypothesis which states that the population has a positive influence on volatile foods in the Province of South Sulawesi is proven to be incompatible with the results of the regression results (table 5).

\section{Conclusion}

Conclusion.

1. The money supply has a positive effect on the volatility of food prices (volatile foods) in the province of South Sulawesi in the period 2011-2017. This means that any increase in the money supply will result in increased volatile foods.

2. Imports of foodstuffs have a positive effect on volatility in food prices in the province of South Sulawesi in the 2011-2017 period. This means that any increase in food imports will result in increased volatile foods.

3. The population has a negative effect on the volatility of food prices (volatile foods) in the Province of South Sulawesi in the period 2011-2017. This means that any increase in population will result in a decrease in the value of volatile foods.

Suggestion.

1. It is expected that the trade sector government should monitor price increases to stabilize the inflation rate, especially foodstuffs.

2. It is hoped that the Bank of Indonesia government will maintain the circulation of money in the community to stabilize the inflation value, especially food

3. It is expected that the government will maintain or suppress food imports so that the price level is more stable.

\section{References}

Anwar, Anas Iswanto, et all. The Role of Financial Inclusion to Poverty Reduction in Indonesia, IOSR Journal of Business and Management Vol.18, Issue 6, Ver.3, Jun-2016.

Arifin. 2007. Diagnosis Ekonomi Politik Pangan dan Pertanian. Jakarta: Raja Grafindo Persada.

Badan pusat statistik. 2015. Berita resmi statistik. Sulawesi Selatan: BPS.

Boediono. 2005. Ekonomi Moneter, Edisi 3, BPFE, Yogyakarta. 
Bourdon MH. 2011. Agricultural Commodity Price Volatility. OECD Food,Agriculture and Fisheries Papers No. 52.

Firdaus M. 2009. Manajemen Agribisnis. Jakarta (ID): Bumi Aksaraisepe

Fischer, Sahay, Vegh. 2002. Modern Hyper and High Inflation. International Monetary Fund Working Paper.

Hadi. 2004, Analisis Keunggulan Komparatif dan Kompetitif Usahatani di Indonesia. Bogor: Department of Economics, Bogor Agricultural University.

Lindert, P.H dan C.P Kindleberger. 1995, "Ekonomi Internasional". Jakarta: Erlangga

Mangilep, M. A. A. (2015). Socioeconomic Problems on Adoption of New Technologies for Production of Paddy Rice by Farmers in Upland Areas of South Sulawesi. 千葉大学人文社会 科学研究, 千葉大学人文社会科学研究 (30), 150-157, 2015-03, 千葉大学大学院人文社会 科学研究科. Retrieved from https://ci.nii.ac.jp/naid/120005940591/

Mankiw G. 2000. Teori Makroekonomi. Imam Nurmawan, penerjemah. Jakarta: Erlangga.

Miguez dan Michelena. 2011. La Volatilidad De Los Precios De Los Commodities El Caso De Los Productos Agrícolas. Buenos Aires: CEI

Mishkin, Frederic S. 2006, The Economics of Addison Weasleyis:

Usman H. 2006. Pendekatan Populer dan Praktis Ekonometrika untuk Analisis Ekonomi dan Keuangan. Jakarta. Lembaga Penerbit Fakultas Ekonomi Universitas Indonesia.

Nurliza. 2017. The nature of food commodity prices volatility in driving inflation and policy. Lembaga Penerbit Fakultas Ekonomi Universitas Tanjung Pura

Prastowo, Nugroho., Tri Yanuarti \& Yoni Depari. (2008). Pengaruh Distribusi Dalam Pembentukan Harga Komoditas dan Implikasinya Terhadap Inflasi. Dalam Working Paper No. WP/07/2008, Bank Indonesia.

Rahardja P dan Manurung M. 2008. Pengantar Ilmu Ekonomi (Mikroekonomi dan Makroekonomi). Edisi Ke-3. Jakarta: Lembaga Penerbit Fakultas Ekonomi UI.

Reza, firdaus dan novianti. 2014. Analyses of food price stabilization in indonesian. Bogor : Department of Economics, Bogor Agricultural University.

Riyadh MI, Oktaviani R, Siregar H. 2009. Analisis fluktuasi nilai tukar rupiah daninflasi Indonesia periode 1999-2006. Jurnal Form Pascasarjana IPB.

Salvatore D. 1997. Ekonomi Internasional, Edisi Kelima. Jilid 1. Jakarta: Penerbit Erlangga.

Santoso T. 2011. Aplikasi model GARCH pada data inflasi bahan makananIndonesia periode 2005. Jurnal Organisasi dan Manajemen

Saputra. 2014. Analisi Kausalitas Harga Beras, Harga Pembelian Pemerintah (HPP) dan Inflasi Serta Efektifitas Kebijakan HPP di Indonesia. Lampung: Lembaga Penerbit Fakultas Pertanian Universitas Lampung

Sugiarto, Herlambang T, Brastoro Sudjana R, Kelana S. 2007. Ekonomi Mikro: Sebuah Kajian Komprehensif. Jakarta: PT Gramedia Pustaka Utama

Sumaryanto. 2009. analisis volatilitas harga eceran beberapa komoditas pangan utama dengan model ARCH/GARCH. Bogor: Pusat Analisis Sosial Ekonomi dan Kebijakan Pertanian.

Tandjung, Marolop. 2011. Aspek dan Prosedur Ekspor-Impor. Jakarta: SalembaEmpat

Walsh JP. 2011. Reconsidering the Role of Food Prices in Inflation. International Monetary Fund Working Paper

Widiarsih D. 2012. Pengaruh sektor komoditi beras terhadap inflasi bahan makanan. Jurnal Sosial Ekonomi Pembangunan. 